\title{
Changes in Body Composition and Physical Fitness According to ACTN-3 Gene Polymorphism in Male Air Force Cadets During 8 Weeks of G-tolerance Exercise Program
}

\author{
Jong-Hwan Choi ${ }^{1}$, Hyun-Seung Rhyu'², Keun-Su Kim³ ${ }^{3}$ In-Ki Kim ${ }^{3 *}$ \\ 'Chungbuk National University, Cheongju, Republic of Korea \\ 2Jungwon University, Goesan, Republic of Korea \\ ${ }^{3}$ Korea Air Force Academy, Cheongju, Republic of Korea
}

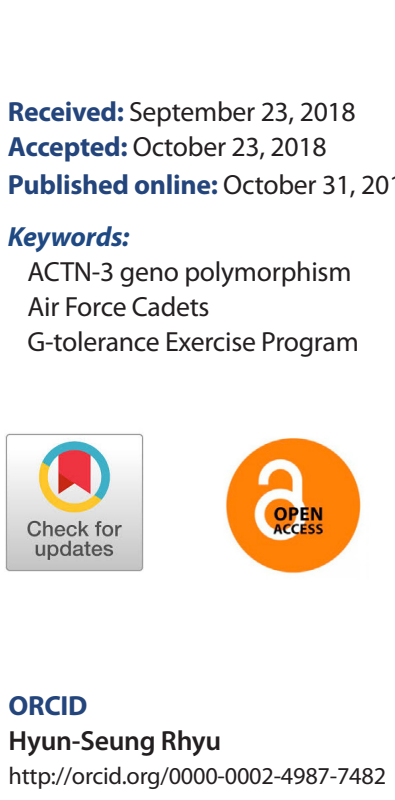

\begin{abstract}
OBJECTIVES This study set out to develop and administer an 8-week G-tolerance reinforcement exercise program and examine changes to the body composition, cardiovascular endurance, isokinetic muscular function, and G-tolerance ability of air force cadets according to the ACTN-3 gene polymorphism, thus testing the effects of the program on air force cadets according to the ACTN-3 gene polymorphism.

METHODS For those purposes, the investigator analyzed the gene polymorphisms of ACTN-3 of 30 air force cadets, administered the developed G-tolerance reinforcement exercise program to and conducted analysis of its effects on their body composition, cardiovascular endurance, isokinetic muscular functions(muscular strength and endurance), and G-tolerance capacity(6G/30sec).

RESULTS Found a significant increase in skeletal muscle mass in the RR and RX types, and body fat percentage in the XX type. the program caused a significant increase to the of the subjects across all the geno types and to their cardiovascular endurance in the RX and XX types. the dominant knee joint(right leg) and found a significant increase in the peak torque per body weight in the RX and XX type. As for the dominant knee joint(right leg), there was a significant increase in the total work per body weight in the RR, RX, and XX types. the G-tolerance ability in the RX than in the RR type, and and G-tolerance ability of XX type was also increased.

CONCLUSIONS In summary, those findings demonstrate that there were differences in the changing patterns of air force cadets' G-tolerance ability according to the ACTN-3 gene polymorphism(RR, RX, and XX) after the G-tolerance reinforcement exercise program and that there was a more increase in the G-tolerance ability in the RX than in the RR type, and G-tolerance ability of XX type was also increased. Therefore, the G-tolerance reinforcement exercise program is verified as effective for reinforcing the G-toleran capacity of air force cadets who have either genotype RX or XX.
\end{abstract}

๑ The Asian Society of Kinesiology and the Korean Academy of Kinesiology

서론

대한민국 공군 조종사는 영공을 수호하는 막중한 임무

*Correspondence: Kim In-Ki, Republic of Korea Air Force Academy, Danjaero 635, P.O. Box 335-2 Namil, Cheongju, Chungbuk Korea.

E-mail:dlsrl0428@hanmail.net
를 가진 국가적으로 매우 중요한 인적자원이다. 이들이 타 군 장교들에 비해 갖는 차별성은 1 차적으로 공중임무에 적합한 신체적 능력을 갖추어야 하며, 두 번째는 이 신체 적 능력을 연령에 무관하게 조종석을 떠날 때까지 최고 수 준으로 유지해야 한다는 점이다.

공군사관학교 생도들은 4 학년 졸업 전(비행입과 전)

(1) This is an open-access article distributed under the terms of the Creative Commons Attribution License (http://creativecommons.org/licenses/by-nc/4.0/), which permits unrestricted use, distribution, and reproduction in any medium, provided the original work is properly cited.

50 | The Asian Journal of Kinesiology 
신체검사를 통과하여야 비행훈련과정에 입문할 수 있 으며, 이어 중급, 고급 비행과정을 거쳐 전투조종사가 된 다. 특히 사관생도들은 비행입과 전 고가속도 테스트에서 $6 \mathrm{G} / 30 \mathrm{sec}$ 를 견뎌내야 하며, G-LOC 등으로 불합격되면 비 행 입문과정에 입문을 못하기 때문에 생도들에게 있어 고 가속도 적응 테스트는 매우 중요한 항목이다.

또한, 공군사관생도들에게 필요한 신체적 능력은 지금 까지의 선행연구들을 종합해 볼 때, 크게 G-내성[1], 공간 지각능력[2], 근골격계 능력[3]으로 정리해볼 수 있다. G내성 (G-tolerance)은 항공기의 급가속시 인체에 주어지는 양가속도 $(+\mathrm{Gz})$ 를 극복하여 뇌의 혈액이 하부로 쏠리는 것을 방지함으로써 의식을 지켜내는 능력이다[4]. F-35나 F-22와 같은 신형 전투기 기종은 최대 $9 \mathrm{G}$ 까지 고가속도가 주어지는데 개인 체중의 9 배의 무게가 머리를 내리누르 는 수준의 힘 부하가 주어지게 된다. 공간지각능력(Spatial Disorientation)은 항공기의 수직, 수평 회전이 반복될 때 몸의 자세를 인지하는 능력이다. 근골격계 능력은 Hi-G 상황과 비상탈출 시 목, 허리 등 관절을 보호하고 골절 등 의 부상을 예방하기 위해서 필요하다.

한편, 유전자에 대한 연구분석은 인간의 능력을 극대 화하거나 노화를 지연시키기 위하여 많은 과학적 노력들 이 활발히 진행중에 있다. 스포츠에서도 1970년대부터 시 작되어 종목별 특성을 충족할 수 있는 적합한 체형, 체력 의 종류와 기능, 신경과 근육의 성분 등을 밝히기 위한 연 구들이 다양하게 이루어지고 있으며 $[5,6,7]$, 이를 토대로 선수선발과 훈련방법 적용에 많은 활용을 하여 좋은 결과 를 나타내고 있다. 특히, 유전자 중 운동수행능력과 밀접 하게 관련된 유전자 중 하나로 ACTN-3 유전자 다형성을 들 수 있다[8]. ACTN-3 유전자 다형성은 스포츠와 관련된 120 개 이상의 유전자 중 유.무산소성 운동 모두와 관련된 소수 유전자 중의 하나로써[9], 근원섬유의 구조적 형태 를 유지하고 근수축을 위한 지지역할을 하며[10], 속근의
최대수축시 에너지 대사를 조절하는 기능에도 관여한다 [11,12]. ACTN-3 유전자 다형성은 RR, RX, XX의 세 형으로 구분되는데, 연구자들마다 차이는 있으나 대다수 연구에 서 RR, RX형은 근력, 순발력 등과 관련되어 무산소성 운 동에 적합하며, $\mathrm{XX}$ 는 지구성 운동에 적합한 것으로 보고 하고 있다 $[10,13,14,15]$.

실제로 전투기 조종사에 게는 근력과 근지구력, 그리고 순발력 적인 체력 요소가 중요한 부분으로 다수의 연구에 서 제시된 바가 있는 데 [4], 만약 ACTN-3 유전자 다형성의 특성을 예비 조종사인 공군 사관생도들을 대상으로 적용 시켜 연구해 본다면 우수 전투기 조종사 양성을 통한 정 예군인 양성에 큰 이바지를 할 것으로 사료된다.

따라서 본 연구에서는 예비조종사인 남자 공군사관생 도들을 대상으로도 $\mathrm{ACTN}-3$ 유전자 다형성을 분석하여 $\mathrm{RR}, \mathrm{RX}, \mathrm{XX}$ 세그룹으로 분류하고, 8 주간의 $\mathrm{G}$-내성을 강 화하기 위한 트레이닝을 실시하여 신체조성, 등속성 근 기능, G-내성능력을 분석하여 사관생도들이 4년간의 교 육기간 동안 어떤 체형을 만들고, 어느 정도의 체력 수준 을 보유하는 것이 조종임무에 적합한지를 알아보고자 본 연구를 진행하였다.

\section{연구 방법}

\section{연구대상}

본 연구의 대상자는 공군 사관생도 4 학년 남생도 74 명 중 유전자 분석과 G-내성능력 결과에 따라 최종 30 명을 연구대상으로 선정하였다. 본 연구는 공군 항공우주의 료원의 '16-2차 기관생명 윤리위원회의 승인(ASMC-16IRB-009)을 받았으며, 본 실험에 참여한 모든 대상자들에 게 연구의 내용과 자료 수집 절차에 대해 서면과 구두로 자세히 설명한 후 실험 참여 동의서를 받고 진행하였다. 대상자들은 평소 규칙적인 생활습관과 의학적으로 특별

Table 1. Physical characteristics of subjects $(M \pm S D)$

\begin{tabular}{ccccc}
\hline Group & Age(yr.) & Height(cm) & Weight(kg) & \%fat \\
\hline $\begin{array}{c}\text { RR type } \\
(\mathrm{n}=10)\end{array}$ & $22.6 \pm 0.72$ & $171.81 \pm 5.10$ & $66.77 \pm 5.70$ & $13.14 \pm 2.86$ \\
$\begin{array}{c}\mathrm{RX} \text { type } \\
(\mathrm{n}=10) \\
\mathrm{XX} \text { type } \\
(\mathrm{n}=10)\end{array}$ & $22.9 \pm 0.55$ & $175.23 \pm 4.45$ & $67.90 \pm 6.28$ & $13.96 \pm 3.63$ \\
\end{tabular}


한 질환이 없는 사관생도로 한정하였으며, 최종 연구 대 상자들의 신체적 특성은 <Table 1>과 같다.

\section{연구방법}

ACTN-3 유전자 분석 실험 대상자들의 동의를 얻어 측 정 전날 저녁 9 시부터 금식을 하여 총 12 시간의 공복 후 오 전 9시에 실시하였으며, 검사 24 시간 전 중강도 이상의 신 체활동을 하지 않도록 하였다. 1회용 주사기(Becton Dickinson Vascurainger System)를 이용하여 실험 참가자의 상 완정맥에서 혈액을 채혈하여 분석하였다.

ACTN-3 유전자 다형성 분석을 위하여 PCR 증폭용 primer 서열을 고안하였다. 올리고 합성은 코스모진텍(한 국)에 의뢰하였다.

ACTN-3의 경우 Sense primer(20mer)는 5'-CAC TGC
TGC CCT TTC TGT TG-3'이고 Antisense primer(19mer) 는 5'-CGG GCT GAG GGT GAT GTA G-3'이었다. amplicon size는 $227 \mathrm{bp}$ 이며 올리고의 2 차 구조 형성여부는 mfold 알 고리즘으로 검증하였다.

연쇄중합반응을 위한 용액은 $10 \mathrm{pM}$ Sense primer, $10 \mathrm{pM}$ Antisense primer, 2.5mM dNTP, 2unit H-Taq DNA polymerase(바이오에세이, 한국), $1 \mathrm{X}$ PCR reaction buffer를 혼합 하였고, Genomic DNA는 $3 \mathrm{uL}$ 씩 첨가하였으며, 총 반응액 이 $20 \mathrm{uL}$ 되도록 하였다. 연 쇄중합 반응은 2720 또는 T100 PCR 장비를 이용하여 수행되었다.

신체조성 측정 대상자들의 신체조성을 분석하기 위해 Inbody 720(Biospace, Korea)을 이용하여 신장, 체중, 체지 방량, $\mathrm{BMI}$, 골격근량, 그리고 체지방률을 측정하였다.

\begin{tabular}{|c|c|c|c|}
\hline Mon & Wed & Thu & Fri \\
\hline muscular strength & muscle endurance & $\begin{array}{c}\text { Cardiopulmonary } \\
\text { endurance }\end{array}$ & muscular strength \\
\hline \multicolumn{4}{|c|}{ Warm-up(running 400m, stretching) } \\
\hline $\begin{array}{c}\text { 1-RM } 85 \% \\
\text { number of repetitions } \\
-8 \text { times } \\
\text { set }-3 \text { set } \\
\text { rest }-3 \text { minutes }\end{array}$ & $\begin{array}{c}\text { 1-RM } 60 \sim 70 \% \\
\text { number of repetitions } \\
\text { - } 15 \text { times } \\
\text { set }-3 \text { set } \\
\text { rest }-30 \text { sec }\end{array}$ & $\begin{array}{c}\text { Target heart rate } \\
\text { (THR=150 170times/ } \\
\text { minutes) } \\
70 \sim 85 \% \\
\text { Exercise time } \\
\text { 30 40minutes }\end{array}$ & $\begin{array}{c}\text { 1-RM } 85 \% \\
\text { number of repetitions } \\
-8 \text { times } \\
\text { set }-3 \text { set } \\
\text { rest - 3minutes }\end{array}$ \\
\hline Bench press & Bench press & & Bench press \\
\hline Leg press & Leg press & & Leg press \\
\hline Lat pull-down & Lat pull-down & & Lat pull-down \\
\hline Leg curl & Leg curl & & Leg curl \\
\hline Arm curl & Arm curl & & Arm curl \\
\hline Sit up & Sit up & & Sit up \\
\hline Leg Extension & Leg Extension & & Leg Extension \\
\hline Triceps Extension & Triceps Extension & & Triceps Extension \\
\hline Calf Raise & Calf Raise & & Calf Raise \\
\hline Military press & Military press & & Military press \\
\hline Squat & Squat & & Squat \\
\hline Abdominal Curl & Abdominal Curl & & Abdominal Curl \\
\hline Neck Exercise & Neck Exercise & & Neck Exercise \\
\hline \multicolumn{4}{|c|}{ Cool-down(stretching) } \\
\hline
\end{tabular}

Figure 1. G-tolerance Reinforcement Exercise Program 
등속성 근기능 측정 등속성 근기능 검사는 Cybex HUMAC NORM770(CSMI, USA) 장비를 이용하여 각 슬관절 의 굴신운동을 수행하도록 하여 근기능을 측정하였다. 피검자는 슬관절을 중심으로 해부학적 자세에서의 $0^{\circ}$ 에 서 $90^{\circ}$ 로 움직이도록 하여 굴곡과 신전 운동을 실시하였 다. 운동 시에는 일정한 운동범위(Range of motion)내에서 진행되도록 한계조정을 하였으며, 측정 시에는 굴곡 및 신전운동을 2 회 예비운동을 실시한 후 측정을 실시하였 다. 측정 시 피검자가 최대 의지력으로 운동을 실시할 수 있도록 실험자가 피검자의 옆에서 독려하였으며, 측정은 $60 \% \mathrm{sec}$ 에서 5 회 실시와 $240 \% \mathrm{sec}$ 에서는 25 회로 측정하고 각각의 운동속도 사이의 휴식시간은 60 초로 설정하였다.

측정내용은 Peak torque(최고 토크), Total work(총 운동 량)로 이를 측정하기 위해 $60 \% \mathrm{sec}, 240 \% \mathrm{sec}$ 로 각각 운동속 도를 변화시켜 좌우측 굴근과 신근의 토크를 측정하였다.

G-내성훈련 공군항공우주의학 훈련센터에서 G-내성 훈련 측정 장비인 곤돌라(ETC, USA)를 이용하여 비행 훈련 입과 자격기준 $(6 \mathrm{G} / 30 \mathrm{sec})$ 으로 실시하였다. G-내성 훈련 방법은 초당 $1 \mathrm{G}$ 씩 상승하는 급가속으로 최대 $6 \mathrm{G}$ 에 $30 \mathrm{sec}$ 간 훈련하였으며, G-내성훈련 중 대상자는 목, 상체, 복부, 하체에 힘을 주어 자세를 유지하고, G-내성 증진 방 법인 L-1 호흡기법을 실시하였다.

트레이닝 프로그램 본 연구에서 사용하는 G-내성을 강 화 하기 위한 트레이닝은 미공군 조종사의 운동프로그램 과 국내 조종사들에 게 제시된 운동프로그램을 토대로 공 군 항공체력(박사) 전문가 4 명, 운동처방 박사 2 명에 게 내 용타당도 검증을 통해 최종 운동프로그램을 구성하였으 며, <Figure 1>와 같다.

근력 및 근지구력 운동프로그램은 4 개의 운동부위(목, 상체, 복부, 하체)로 나누어 총 13 개의 부위별 운동종목을 구성하여 주 3 회(근력 2회, 근지구력 1 회)를 실시하였다. 심폐지구력은 사관학교 교과과정을 연계하여 주 1 회 실 시하였다.

자료처리 방법 자료는 SPSS ver. 22.0(for windows)을 이 용하여 사관생도의 ACTN-3 유전자 다형성에 따른 세 집 단의 사전 동질성을 알아보기 위해 일원변량분석(oneway ANOVA)을 실시하였으며, 유전자 다형성별 운동프 로그램 실시 후 각 변인의 변화차이를 알아보기 위하여
반복측정 변량분석(Repeated measurement ANOVA)을 실 시하였다. 유의한 상호작용이 나타난 경우 Tukey의 HSD 를 사용하여 사후검증(Post-hoc comparison)을 실시하였 다. 유의수준은 $\mathrm{p}<.05$ 수준으로 하였다.

\section{결과}

\section{연구대상자의 사전 동질성 검사}

공군 사관생도의 ACTN-3 유전자 형태에 따른 집단 간 사전 동질성 검사를 위해 일원변량분석(one-way ANO$\mathrm{VA}$ )을 실시하였으며 그 결과는 <Table $2>$ 와 같다. 그 결 과 모든 변인(골격근량, 체지방률, 심폐지구력, 슬관절 등 속성 능력에서 유의한 차이가 나타나지 않았다. 따라서 ACTN-3 유전자 다형성에 따른 세 집단은 동일한 집단이 라고 할 수 있다.

\section{ACTN-3 유전자 다형성별 운동프로그램에 따른 신체조} 성, 심폐지구력 차이 몸공군 사관생도의 ACTN-3 유전자 다형성별(RR, RX, XX) 8주간 G-내성을 강화하기 위한 트 레이닝에 따른 신체조성(골격근량, 체지방률)과 심폐지 구력 $(\mathrm{ml} / \mathrm{kg} / \mathrm{min})$ 의 차이를 검증하기 위해 반복측정 변량 분석(Repeated measures ANOVA)을 실시하였으며, 그 결 과는 < Table 3>과 같다.

골격근량 $(\mathrm{kg})$ 은 ACTN-3 유전자 다형성과 시간에 따른 상호작용 효과가 유의하지 않게 나타났으며 $(\mathrm{p}=.787)$, 집 단 내 변화를 살펴본 결과 $\mathrm{RR}$ 형 $(\mathrm{p}=.047)$ 과 $\mathrm{RX}$ 형 $(\mathrm{p}=.003)$ 에서 8 주간의 G-내성 강화 운동프로그램 후 사전보다 골 격근량이 유의하게 증가하였다. 한편 XX형 $(\mathrm{p}=.158)$ 의 경 우 유의한 변화가 없는 것으로 나타났다.

체지방률(\%)은 ACTN-3 유전자 다형성과 시간에 따른 상호작용 효과가 유의하지 않게 나타났으며 $(\mathrm{p}=.314)$, 집 단 내 변화를 살펴본 결과 XX형 $(\mathrm{p}=.030)$ 에서 8 주간의 $\mathrm{G}-$ 내성 강화 운동프로그램 후 사전보다 체지방률이 유의하 게 증가하였다. 한편 $\mathrm{RR}$ 형 $(\mathrm{p}=.939)$ 과 $\mathrm{RX}$ 형 $(\mathrm{p}=.097)$ 의 경 우 유의한 변화가 없는 것으로 나타났다.

심폐지구력은 ACTN-3 유전자 다형성과 시간에 따 른 상호작용 효과가 유의하지 않게 나타났으며 $(\mathrm{p}=.894)$, 집단 내 변화를 살펴본 결과 $\mathrm{RX}$ 형 $(\mathrm{p}=.001)$ 과 $\mathrm{XX}$ 형 집단 $(\mathrm{p}=.011)$ 에서 8주간의 $\mathrm{G}$-내성 강화 운동프로그램 후 심폐 지구력이 유의하게 증가하였다. 한편 RR형 집단의 경우 유의한 변화가 없는 것으로 나타났다( $\mathrm{p}=.134)$. 
Table 2. Pre-homogeneity check

\begin{tabular}{|c|c|c|c|c|c|c|}
\hline \multicolumn{2}{|c|}{ Item } & \multicolumn{3}{|c|}{ Group } & \multirow{2}{*}{$F(t)$} & \multirow{2}{*}{ p } \\
\hline & & RR & RX & $X X$ & & \\
\hline \multirow{2}{*}{$\begin{array}{c}\text { Body } \\
\text { composition }\end{array}$} & $\begin{array}{c}\text { skeletal muscle } \\
\operatorname{mass}(\mathrm{kg})\end{array}$ & $32.88 \pm 2.82$ & $33.04 \pm 2.67$ & $34.63 \pm 2.46$ & $1.322(2)$ & .283 \\
\hline & $\%$ fat & $13.13 \pm 2.00$ & $13.93 \pm 2.99$ & $12.74 \pm 2.96$ & $.507(2)$ & .608 \\
\hline \multicolumn{2}{|c|}{ Cardiopulmonary endurance $(\mathrm{ml} / \mathrm{kg} / \mathrm{min})$} & $49.33 \pm 8.74$ & $47.43 \pm 8.63$ & $51.79 \pm 8.49$ & $.643(2)$ & .534 \\
\hline \multicolumn{2}{|l|}{ Extension } & $277.40 \pm 40.84$ & $288.50 \pm 31.70$ & $283.10 \pm 36.85$ & $0.229(2)$ & .797 \\
\hline \multicolumn{2}{|l|}{ Flexion } & $179.60 \pm 16.78$ & $202.30 \pm 28.31$ & $198.60 \pm 26.45$ & 2.495(2) & .101 \\
\hline \multicolumn{2}{|c|}{ FL/EX ratio(\%) } & $69.20 \pm 6.90$ & $68.80 \pm 10.44$ & $74.70 \pm 8.98$ & $1.373(2)$ & .270 \\
\hline Extension & total work/ & $3545.00 \pm 371.71$ & $3407.60 \pm 477.32$ & $3456.50 \pm 363.41$ & $0.292(2)$ & .749 \\
\hline Flexion & BW(\%) & $3365.50 \pm 453.31$ & $3026.50 \pm 310.03$ & $3319.70 \pm 351.54$ & $2.387(2)$ & .111 \\
\hline \multicolumn{2}{|c|}{ FL/EX ratio(\%) } & $95.70 \pm 11.86$ & $91.70 \pm 10.92$ & $93.60 \pm 21.00$ & $0.171(2)$ & .843 \\
\hline \multicolumn{2}{|c|}{ G-tolerance (sec) } & $21.57 \pm 8.810$ & $12.86 \pm 8.071$ & $14.00 . \pm 8.406$ & $2.207(2)$ & .139 \\
\hline
\end{tabular}

Table 3. Difference between body composition and cardiovascular endurance

\begin{tabular}{|c|c|c|c|c|c|c|}
\hline Factor & Group & $\begin{array}{c}\text { pre } \\
(M \pm S D)\end{array}$ & $\begin{array}{c}\text { post } \\
(\mathrm{M} \pm S D)\end{array}$ & $t(d f)$ & $p$ & Time*Group \\
\hline \multirow{3}{*}{ skeletal muscle mass(kg) } & RR & $32.88 \pm 2.82$ & $33.76 \pm 3.14$ & $-2.302(9)$ & $.047^{*}$ & \multirow{3}{*}{$\begin{array}{c}F(2)=.241 \\
p=.787\end{array}$} \\
\hline & RX & $33.04 \pm 2.67$ & $33.84 \pm 2.54$ & $-4.068(9)$ & $.003^{*}$ & \\
\hline & $x X$ & $34.63 \pm 2.46$ & $35.20 \pm 2.55$ & $-1.539(9)$ & .158 & \\
\hline \multirow{3}{*}{ fat(\%) } & $\mathrm{RR}$ & $13.13 \pm 2.00$ & $13.20 \pm 2.24$ & $-.079(9)$ & .939 & \multirow{3}{*}{$\begin{array}{c}F(2)=1.211 \\
p=.314\end{array}$} \\
\hline & $\mathrm{RX}$ & $13.93 \pm 2.99$ & $15.73 \pm 2.74$ & $-1.855(9)$ & .097 & \\
\hline & $x X$ & $12.74 \pm 2.96$ & $14.14 \pm 3.33$ & $-2.570(9)$ & $.030^{*}$ & \\
\hline \multirow{3}{*}{$\begin{array}{l}\text { Cardiopulmonary endurance } \\
\qquad(\mathrm{ml} / \mathrm{kg} / \mathrm{min})\end{array}$} & $\mathrm{RR}$ & $49.33 \pm 8.74$ & $52.25 \pm 7.04$ & $-1.645(9)$ & .134 & \multirow{3}{*}{$\begin{array}{c}F(2)=.112 \\
p=.894\end{array}$} \\
\hline & $\mathrm{RX}$ & $47.43 \pm 8.63$ & $51.43 \pm 6.81$ & $-5.185(9)$ & $.001^{* *}$ & \\
\hline & $X X$ & $51.79 \pm 8.49$ & $55.96 \pm 8.26$ & $-3.185(9)$ & $.011^{*}$ & \\
\hline
\end{tabular}

결과적으로 8주간의 G-내성을 강화하기 위한 트레이 닝 후 ACTN-3 유전자 다형성별 신체조성의 변화를 알아 본 결과 RR형과 RX형 집단에서 골격근량 $(\mathrm{kg})$ 이 증가되었 으며, XX형 집단에서는 체지방률(\%)이 증가되었으며, 심 폐지구력에서는 RX형, XX형 집단에서 증가되었다.

\section{ACTN-3 유전자 다형성별 운동프로그램에 따른 등속} 성 근기능, G-내성능력 차이 공군 사관생도의 ACTN-3 유 전자 다형성별 $(\mathrm{RR}, \mathrm{RX}, \mathrm{XX}) 8$ 주간 $\mathrm{G}$-내성을 강화하기 위 한 트레이닝에 따른 슬관절 등속성 근력(60/sec), 근지구 력(240/sec), G-내성능력(6G/30sec) 차이를 검증하기 위해
반복측정 변량분석(Repeated measures ANOVA)을 실시하 였으며, 그 결과는 <Table 4>와 같다.

근력의 경우 Extension 시 체중 당 최대토크(PT/BW)는 ACTN-3 유전자 다형성과 시간에 따른 상호작용 효과가 유의하지 않게 나타났다( $\mathrm{p}=.736)$. 그러나 집단 내 변화를 살펴본 결과 $\mathrm{RX}$ 형 집단에서 8 주간의 $\mathrm{G}$-내성 강화 운동프 로그램 후사전보다 체중 당 최대토크가 유의하게 증가하 였다 $(\mathrm{p}=.028)$. 한편 $\mathrm{RR}$ 형 $(\mathrm{p}=.344)$ 과 $\mathrm{XX}$ 형 $(\mathrm{p}=.384)$ 집단의 경우 유의한 변화가 없는 것으로 나타났다.

Flexion 시 체중 당 최대토크(PT/BW)는 ACTN-3 유전 자 다형성과 시간에 따른 상호작용 효과가 유의하지 않게 
Table 4. Muscle strength $(60 \% / \mathrm{sec})$, muscle endurance difference( $240 \% \mathrm{sec})$, G-tolerance(sec)

\begin{tabular}{|c|c|c|c|c|c|c|c|}
\hline Factor & & Group & $\begin{array}{c}\text { pre } \\
(M \pm S D)\end{array}$ & $\begin{array}{c}\text { post } \\
(M \pm S D)\end{array}$ & $t(d f)$ & $p$ & Time*Group \\
\hline \multirow{3}{*}{ EX } & \multirow{3}{*}{$\begin{array}{l}\text { PT/BW } \\
(\%)\end{array}$} & RR & $277.40 \pm 40.84$ & $281.00 \pm 39.73$ & $-.999(9)$ & .344 & \multirow{3}{*}{$\begin{array}{c}F(2)=.310 \\
p=.736\end{array}$} \\
\hline & & $\mathrm{RX}$ & $288.50 \pm 31.70$ & $295.00 \pm 26.91$ & $-2.619(9)$ & $.028^{*}$ & \\
\hline & & $X X$ & $283.10 \pm 36.85$ & $286.30 \pm 38.57$ & $-.915(9)$ & .384 & \\
\hline \multirow{3}{*}{$\mathrm{FL}$} & \multirow{3}{*}{$\begin{array}{l}\text { PT/BW } \\
(\%)\end{array}$} & RR & $179.60 \pm 16.78$ & $192.30 \pm 17.21$ & $-1.968(9)$ & .081 & \multirow{3}{*}{$\begin{array}{c}F(2)=.401 \\
p=.674\end{array}$} \\
\hline & & $\mathrm{RX}$ & $202.30 \pm 28.31$ & $209.40 \pm 20.43$ & $-1.623(9)$ & .139 & \\
\hline & & $X X$ & $198.60 \pm 26.45$ & $206.50 \pm 27.64$ & $-2.815(9)$ & $.020^{*}$ & \\
\hline \multirow{3}{*}{ Ratio FL/EX(\%) } & \multirow{6}{*}{$\begin{array}{c}\text { TW/BW } \\
(\%)\end{array}$} & RR & $69.20 \pm 6.90$ & $71.40 \pm 7.16$ & $-2.310(9)$ & $.046^{*}$ & \multirow{3}{*}{$\begin{array}{c}F(2)=1.364 \\
p=.273\end{array}$} \\
\hline & & $\mathrm{RX}$ & $68.80 \pm 10.44$ & $76.30 \pm 8.12$ & $-2.101(9)$ & .065 & \\
\hline & & $x X$ & $74.70 \pm 8.98$ & $78.90 \pm 8.58$ & $-2.894(9)$ & $.018^{*}$ & \\
\hline \multirow{3}{*}{ EX } & & $\mathrm{RR}$ & $3545.00 \pm 371.71$ & $3671.60 \pm 411.74$ & $-4.965(9)$ & $.001^{* *}$ & \multirow{3}{*}{$\begin{array}{c}F(2)=3.273 \\
p=.053\end{array}$} \\
\hline & & $\mathrm{RX}$ & $3407.60 \pm 477.32$ & $3446.00 \pm 421.81$ & $-.834(9)$ & .426 & \\
\hline & & $x X$ & $3456.50 \pm 363.41$ & $3774.10 \pm 357.07$ & $-2.519(9)$ & $.033^{*}$ & \\
\hline \multirow{3}{*}{$\mathrm{FL}$} & \multirow{3}{*}{$\begin{array}{c}\text { TW/BW } \\
(\%)\end{array}$} & RR & $3365.50 \pm 453.31$ & $3407.70 \pm 412.05$ & $-1.066(9)$ & .314 & \multirow{3}{*}{$\begin{array}{c}F(2)=2.698 \\
p=.085\end{array}$} \\
\hline & & $\mathrm{RX}$ & $3026.50 \pm 310.03$ & $3291.80 \pm 273.07$ & $-2.289(9)$ & $.048^{*}$ & \\
\hline & & $X X$ & $3319.70 \pm 351.54$ & $3355.30 \pm 333.87$ & $-.562(9)$ & .588 & \\
\hline \multirow{3}{*}{ FL/EX ration(\%) } & & $\mathrm{RR}$ & $95.70 \pm 11.86$ & $99.20 \pm 8.24$ & $-2.400(9)$ & $.040^{*}$ & \multirow{3}{*}{$\begin{array}{c}F(2)=.511 \\
p=.606\end{array}$} \\
\hline & & $\mathrm{RX}$ & $91.70 \pm 10.92$ & $97.80 \pm 11.94$ & $-2.672(9)$ & $.026^{*}$ & \\
\hline & & $x X$ & $93.60 \pm 21.00$ & $96.10 \pm 24.56$ & $-.776(9)$ & .458 & \\
\hline \multirow{3}{*}{ G-tolerance (sec) } & & $\mathrm{RR}$ & $21.57 \pm 8.810$ & $26.29 \pm 9.827$ & $-1.451(6)$ & .197 & \multirow{2}{*}{$\begin{array}{c}F(2)=3.830 \\
p=.041\end{array}$} \\
\hline & & RX & $12.86 \pm 8.071$ & $30.00 \pm 0.000$ & $-5.620(6)$ & $.001^{* *}$ & \\
\hline & & $x X$ & $14.00 . \pm 8.406$ & $24.57 \pm 10.628$ & $-3.275(6)$ & $.017^{*}$ & $(\mathrm{RX}>\mathrm{RR})$ \\
\hline
\end{tabular}

나타났다(p=.674). 그러나 집단 내 변화를 살펴본 결과 XX 형 집단에서 8 주간의 G-내성 강화 운동프로그램 후 사전 보다 체중 당 최대토크가 유의하게 증가하였다 $(\mathrm{p}=.020)$. 한편 $\mathrm{RR}$ 형 $(\mathrm{p}=.081)$ 과 $\mathrm{RX}$ 형 $(\mathrm{p}=.139)$ 집단의 경우 유의한 변화가 없는 것으로 나타났다.

굴근/신근 비율(FL/EX ratio)은 ACTN-3 유전자 다형 성과 시간에 따른 상호작용 효과는 유의하지 않게 나타 났다 $(\mathrm{p}=.273)$. 그러나 집단 내 변화를 살펴 본 결과 $\mathrm{RR}$ 형 $(\mathrm{p}=.046)$ 과 $\mathrm{XX}$ 형 집단 $(\mathrm{p}=.018)$ 에서 8 주간의 $\mathrm{G}$-내성 강화 운동프로그램 후 사전보다 굴근/신근 비율은 유의하게 증가하였다. 한편 RX형 집단의 경우 유의한 변화가 없는 것으로 나타났다 $(\mathrm{p}=.065)$.

근지구력의 경우 Extension 시 체중 당 총운동량(TW/ $\mathrm{BW}$ )은 ACTN-3 유전자 다형성과 시간에 따른 상호작용 효과가 유의하지 않게 나타났으며( $\mathrm{p}=.053)$, 집단 내 변화 를 살펴본 결과 $\mathrm{RR}$ 형 $(\mathrm{p}=.001)$ 과 $\mathrm{XX}$ 형 집 단 $(\mathrm{p}=.033)$ 에서 8
주간의 G-내성 강화 운동프로그램 후 체중 당 총운동량이 사전보다 유의하게 증가하였다. 한편 $\mathrm{RX}$ 형 집단의 경우 유의한 변화가 없는 것으로 나타났다 $(\mathrm{p}=.426)$.

Flexion 시 체중 당 총운동량(TW/BW)은 ACTN-3 유전 자 다형성과 시간에 따른 상호작용 효과가 유의하지 않 게 나타났으며 $(\mathrm{p}=.085)$, 집단 내 변화를 살펴본 결과 $\mathrm{RX}$ 형 집단에서 8 주간의 G-내성 강화 운동프로그램 후 체중 당 총운동량이 유의하게 증가하였다 $(\mathrm{p}=.048)$. 한편 $\mathrm{RR}$ 형 $(\mathrm{p}=.314)$ 과 XX형 집 단( $\mathrm{p}=.588)$ 의 경우 유의한 변화가 없는 것으로 나타났다.

굴근/신근 비율(FL/EX ratio)은 ACTN-3 유전자 다형성 과 시간에 따른 상호작용 효과는 유의하지 않게 나타났 으며 $(\mathrm{p}=.606)$, 집단 내 변화를 살펴본 결과 $R R$ 형 $(\mathrm{p}=.040)$ 과 $\mathrm{RX}$ 형 집단 $(\mathrm{p}=.026)$ 에서 8 주간의 $\mathrm{G}$-내성 강화 운동프 로그램 후 굴근/신근 비율이 유의하게 증가하였다. 한편 $\mathrm{XX}$ 형 집단의 경우 유의한 변화가 없는 것으로 나타났다 
$(\mathrm{p}=.458)$.

G-내성능력은 ACTN-3 유전자 다형성과 시간에 따른 상호작용 효과가 유의하게 나타났다 $(\mathrm{p}=.041)$. 이는 유전 자 다형성과 $\mathrm{G}$-내성 강화 운동프로그램은 상호의존성을 갖고 $\mathrm{G}$-내성 능력 향상에 긍정적인 영향을 준다는 것을 말한다. 구체적으로 알아보기 위해 사후 검증(post-hoc)을 실시한 결과 RX형과 RR형 집단의 G-내성능력 간에 유의 한 차이를 보임으로써 $(\mathrm{p}=.041), 8$ 주간의 $\mathrm{G}$-내성 강화 운동 프로그램 후 RR형 집단에 비해 RX형 집단의 G-내성능력 이 더 증가된 것으로 나타났다. 또한 집단 내 변화를 살펴 본 결과 $\mathrm{RX}$ 형 $(\mathrm{p}=.001)$ 과 $\mathrm{XX}$ 형 집단 $(\mathrm{p}=.017)$ 에서 8 주간의 G-내성을 강화하기 위한 트레이닝 후 G-내성능력이 유의 하게 증가하였다.

\section{논의}

본 연구는 G-내성을 강화하기 위한 트레이닝을 8주(주 4 회)간 실시한 후 공군 사관생도의 ACTN-3 유전자 다형 성 $(\mathrm{RR}, \mathrm{RX}, \mathrm{XX})$ 에 따른 신체조성, 심폐지구력, 등속성 근 기능, G-내성능력 $(6 \mathrm{G} / 30 \mathrm{sec})$ 의 변화차이를 규명하여 공 군 사관생도의 ACTN-3 유전자 다형성별 G-내성 강화 운 동프로그램의 효과를 검증하였다.

본 연구에서는 8주간 G-내성을 강화하기 위한 트레이 닝 후 ACTN-3 유전자 다형성별 골격근량 $(\mathrm{kg})$ 의 변화를 살펴보았다. 골격근량의 경우 트레이닝 후 RR형과 RX형 집단에서 골격근량이 증가되었다. ACTN-3 유전자 다형 성 중 $\mathrm{RR}$ 형과 $\mathrm{RX}$ 형은 속근에서 발현하여 속근의 Z-line 을 형성하여 속근섬유의 근수축을 유도하지만, ACTN-3 유전자 다형성 중 XX형은 $\alpha$-actinin-3을 전혀 발현하지 못 한다[14]. 따라서 본 연구에서 실시한 트레이닝 중 저항성 트레이닝에 따른 RR형과 RX형의 골격근량 증가는 이와 같은 유전자 특성에 따라 속근 섬유의 근수축을 유도하 여 근섬유가 증가한 것으로 사료된다. 또한, 고강도의 저 항성 트레이닝이 근력을 증가시키고, 운동기간 동안 근육 량을 유지 또는 증가시킬 수 있다고 보고되어[16], 본 연구 에서 실시한 G-내성 강화 운동프로그램이 고강도의 저항 성 프로그램으로 구성되었기 때문에 나타난 결과라 생각 된다. 조종사에 게 있어 골격근량은 G-내성능력에 도 영향 을 미치는 중요한 요인이다. 조종사가 $+\mathrm{Gz}$ 가속도에 노출 되면 뇌혈류량을 유지하기 위해 동맥압을 상승시키는데 [17]의 연구에 의하면 $+5 \mathrm{Gz}$ 에서 $140 \mathrm{mmHg}$ 이며, $+10 \mathrm{Gz}$ 에
서는 $180 \mathrm{mmHg}$ 그리고 $+15 \mathrm{Gz}$ 에서는 $220 \mathrm{mmHg}$ 까지 동맥 압이 증가한다고 하였다. 고가속도 환경에서 동맥압을 상 승시킬 수 있는 요인으로는 근육의 정적 수축에 의해 말 초저항이 상승하였기 때문이다. 결국 조종사가 $+\mathrm{Gz}$ 내성 을 상승시키기 위해서는 근육의 크기를 키워 정적 수축력 을 증가시켜야 하는 것이다[18]. 체지방률의 경우 8 주간 의 G-내성 강화 운동프로그램 후 XX형 집단의 체지방률 이 증가되었다.

[18]의 연구에서는 공군 사관생도를 대상으로 G-내성 을 검사를 실시하여 신체조성이 G-내성능력에 미치는 영 향을 연구한 결과, 상대적으로 높은 $\mathrm{BMI}$ 를 가지고 있는 대상자가 G-내성능력에 긍정적인 영향을 준 것으로 나타 났다. 이는 급격하게 증가하는( 1 초에 $1 \mathrm{G}$ 씩 증가) $\mathrm{G}$-내성 을 견디기 위해서는 상대적으로 높은 BMI가 필요함을 시 사한다.

심폐지구력의 경우 8주간 G-내성을 강화하기 위한 트 레이닝 후 $\mathrm{RX}$ 형과 $\mathrm{XX}$ 형 집단의 심폐지구력이 증가되었 다. 이러한 연구결과는 쇼트트랙 스피드스케이트 국가대 표 남자선수 20 명을 대상으로 한 연구에서 XX형이 지구 성 운동에서 강점을 보인다고 제시하고[10], 있어 본 연구 결과에서 나타난 RX형, XX형의 심폐지구력 증가는 지구 성 능력과 관련 있기 때문에 선행연구의 결과를 뒷받침할 수 있는 것으로 나타났다. 또한, 호주 국가대표 선수 429명 의 ACTN-3 유전자 다형성 분포를 분석한 연구에 따르면 무산소성능력과 관련된 근력과 스프린트 종목에서 RR형 과 RX형의 빈도가 높은 반면, 지구성 선수들에 게서는 XX 형의 빈도가 유의하게 높게 나타났다고 보고하였다[14]. 핀란드 엘리트 운동선수 141 명을 대상으로 ACTN-3 유전 자 다형성을 비교한 연구결과 지구력 선수들에 게 RR형에 비해 XX형의 빈도가 높은 것으로 나타났다고 보고하였 다[19]. 이와 관련한 국내 연구로는 일반인(410명)과 국가 대표선수(458명)를 대상으로 실시한 연구에서 지구성 종 목에서는 ACTN-3 유전자 다형성 중 XX형의 영향력이 크 게 작용할 수 있다고 보고하고[20], 있어 본 연구의 결과를 뒷받침하는 결과로 사료된다.

슬관절 등속성 근력의 변화를 살펴본 결과 8 주간 G-내 성을 강화하기 위한 트레이닝 후 RX형과 $\mathrm{XX}$ 형 집단에서 최대근력(체중 당 최고토크)이 증가하였고, $\mathrm{RR}$ 형과 $\mathrm{XX}$ 형에서 굴근과 신근의 비율이 향상되었다.

이러한 연구결과는 주 3회 10 주간 저항성 트레이닝 후 최대근력에서 ACTN-3 유전자 다형성간 유의한 차이가 
나타나지 않았으나 저항성 트레이닝 후 RR형, RX형, $\mathrm{XX}$ 형 집단에서 최대근력(체중당 피크토크)이 향상되었음을 보고한 연구와 유사한 결과를 보였다[15]. 12주간의 근력 트레이닝 후 XX형에서 근력이 증가하였다는 연구결과를 보고하고[21], 있어 본 연구결과와 일부 유사한 결과를 나 타내고 있다.

슬관절 등속성 근지구력의 변화를 살펴본 결과 8 주간 G-내성을 강화하기 위한 트레이닝 후 RR형, RX형, XX형 집단 모두에서 근지구력(체중 당 최고토크)이 증가하였 고, RR형과 RX형 집단에서 굴근과 신근의 비율이 향상되 었다.

본 연구의 결과는 10 주간 저항운동을 통해 $\mathrm{RR}$ 형, $\mathrm{RX}$ 형, XX형 집단 모두 근지구력이 증가한 연구와 유사한 결 과를 나타내었다[15]. 이러한 결과는 $\alpha$-actinin-3 단백질이 속근섬유의 형성을 촉진하거나 운동훈련에 따른 당대사 를 변화시키며, 반복적인 운동에 의해 야기되는 $\alpha$-actinin 을 포함한 단백질의 저하와 형태학적인 손상에 가장 민감 한 구조를 가진 속근 내 Z-선의 손상을 최소화시키기 [22], 때문에 나타난 결과로 생각된다. 또한 XX형 집단의 근지 구력도 발달한 것으로 나타났는데, 이는 XX형 유전자형 이 속근에서 $\alpha$-actinin-3가 발현되지 않고, 지근에서 $\alpha$-actinin-2가 발현되어 지구성 운동수행 능력을 향상시킨 것 [23]이라 생각된다.

$\mathrm{G}$-내성능력의 변화를 살펴본 결과 8주간 G-내성을 강 화하기 위한 트레이닝 후 RR형 집단에 비해 RX 집단의 G내성능력을 더 증가시키고, XX형 집단의 G-내성능력도 증가시키는 것으로 나타났다. 정상적으로 속근에서 $\alpha$-actinin-3가 존재하며, 최대근력을 발휘하는 무산소성(근력/ 파워)운동 종목 선수들에 게 유리한 RR형보다지구성능력 에도 관련 있는 RX형에서 $\mathrm{G}$-내성능력이 더 크게 증가한 것을 알 수 있다. 이는 이형접합체(heteroztgous; RX형)의 경우 지구성능력과도 관련성이 있다고 선행연구에서 예 측하고[24], 있기 때문에 근력과 지구성 능력이 G-내성능 력 강화에 있어 발달시켜야 하는 신체적 능력으로 사료된 다.

[25]의 연구에 따르면 무산소성 운동능력은 RR형과 높 은 관련성이 있으며, 파워 관련 종목과 육상 단거리 달리 기 선수들에게서 RR형의 빈도가 높게 나타났다고 보고하 였다. 또한, [26]의 연구에서는 크로스컨트리 스키 선수들 의 ACTN-3 유전자 분포에 따른 유·무산소성 능력의 차이 를 분석한 결과, 유산소성 능력이 뛰어난 선수들은 XX형
의 빈도가 높게 나타났다고 보고하여 선행연구를 통해 유 전자 다형성 특성에 따라 신체적 능력에도 차이가 있는 것 을 알 수 있다. 선행연구에서 제시한 ACTN-3 유전자 다형 성별 특성에 따라 본 연구에서 나타난 G-내성능력 변화패 턴에는 근력뿐만 아니라 근지구력과 유산소성 능력이 영 향을 미치는 것으로 사료된다. 이는 G-내성능력이 선행연 구에서 제시된 최대근력 향상뿐만 아니라 근지구력과 심 폐지구력의 향상이 중요한 영향을 미치고 있음을 제시해 주고 있다. 하지만 선행연구에서는 G-내성능력을 견디기 위해 최대근력을 발달시켜 high-G 상황에서 나타나는 뇌 혈류량 감소에 의한 의식상실을 지켜내야 한다고 하였으 며[4], [27]의 연구에서도 12주간의 저항성 트레이닝으로 최대근력을 발달시켜 G-내성능력을 강화할 수 있다고 보 고하였다.

\section{결론}

공군 사관생도들은 G-내성을 강화하기 위하여 트레이 닝을 실시 후 ACTN-3 유전자 다형성별 G-내성능력 변화 패턴에 차이가 나타나 RR형에 비해 RX형 사관생도들의 G-내성능력이 더 크게 증가되었으며, XX형 사관생도들 의 G-내성능력도 증가되었다. 따라서 G-내성을 강화하기 위한 트레이닝이 RX형과 XX형의 유전자형을 가진 공군 사관생도들에게 효과적인 트레이닝방법 이라는 것을 검 증할 수 있었다.

따라서, 본 연구에서 실시한 8주간의 G-내성을 강화하 기 위한 트레이닝은 공군사관생도들의 G-내성능력 강화 에 긍정적인 영향을 미쳤으며, 향후 G-내성능력이 부족한 기성조종사와 생도들에 게 8주 이상의 운동프로그램을 적 용시켜 그 변화를 확인하면서 지속적인 연구가 이루어질 필요가 있다고 제언한다.

\section{Conflicts of Interest}

The authors declare no conflict of interest.

\section{References}

1. Eiken O, Mekajavic L, Sunblad P, Kolegard R. G tolerance vis-a-vis pressure distension and pressure-flow relationships of leg arteries. Eur J Appl Physiol. 2012; 
112:3619-3627.

2. Cheung B. Spatial disorientation: more than just illusion. Aviat Space Environ Med. 2013; 84(11):1211-1214.

3. Manen O, Clement J, Bisconte S, Perrier E. Spine injuries related to high performance aircraft ejections: a 9-year retrospective study. Aviat Space Environ Med. 2014; 85(1):66-70.

4. Koo MS. Physical fitness program to enhance aircrew $\mathrm{G}$ tolerance. J Korea Exerc Sci Acad. 2002; 11(1):211-220.

5. Chiu LL, Hsieh LL, Yen KT, Hsieh SS. Ace I/d And ACTN-3 R577x polymorphism in elite athletes. Med Sci Sport Exerc. 2005; 37(5):167.

6. Kim CH, Kim YM. Association of the ACTN3 single-nucleotide polymorphism with mechanical-power performance in Korean population. Korean J Sport Stud. 2005; 44(6):465-474.

7. Clarkson PM, Devaney JM, Gordish DH, et al. ACTN3 genotype is associated with increases in muscle strength in response to resistance training in woman. J Appl Sport Psychol. 2005; 99(1):154-63.

8. Eynon N, Alves AJ, Yamin C, Sagiv M, Meckel Y. Is there an ACE ID-ACTN-3 R577X polymorphisms interaction that influences sprint performance. J Sport Med. 2009; 30(12):888-891.

9. Rankinen TL, Perusse R, Rauramaa MA, Rivera BW, Bouchard C. The human gene map for Performance and health-related fitness phenotypes. Med Sci Sports Exerc. 2001; 34(8):1219-1233.

10. Kim JW, Lee KH, Yun SJ. The comparison of aerobic and anaerobic capacity to excellent men's short track skater and speed skater. Korean J Sports Sci. 2014; 23(4):1143-1151.

11. Friden J, Lirber RL. Serum creatine kinase level is a poor predictor of muscle function after injury. Scand J Med Sci Sports. 2001; 11(2):126-127.

12. MacArthur DG, North KN. Genes and human athletic performance. Hum Genet. 2005; 116(5):331-339.

13. Cho HC, Kim JK, Kim SY, et al. Change of an \&aerobic capacity on long term training between ACTN-3 polymorphism. J Korean Alliance Martial Arts. 2013; 15(1):43-55.
14. Yang N, MacArthur DG, Gulbin JP, et al. ACTN-3 genotype is associated with human elite athletic performance. Am J Hum Genet. 2013; 73:627-631.

15. Shin YA, Kim SJ. Effects of muscle strength, muscle power, and muscle endurance following resistance training according to ACTN3 genotype. Korean J Sport Stud. 2010; 49(3):329-341.

16. Taaffe DR, Duret C, Wheeler S, Marcus R. Once weekly resistance exercise improves muscle strength and neuromusclar performance in older adults. J National Acad Sci Online(US). 1999; 97(26):14632-14637.

17. Balldin VI. Physical training and $+\mathrm{Gz}$ tolerance. Aviat Space Environ Med. 1984; 55:991-992.

18. Park JS. Effect of isokinetic muscular function on G-tolerance(+6G/30s). J Korean Soc Wellness. 2015; 10(3):213-220.

19. Niemi AK, Majamaa K. Mitochondrial DNA and ACTN3 genotypes in Finnish elite endurance and sprint athletes. European J Hum Genet. 2005; 13(8):965-969.

20. Kim YJ, Park DH, Sung BJ, et al. Relationship between ACTN3 polymorphism and power-endurance performance. Phys Educ Sci Res. 2006; 17(1):55-65.

21. Lee JH, Park NS. Interaction of ACTN3 gene polymorphism and muscle imbalance effects on kinematic efficiency in combat sports athletes. J Exerc Nutrition Biochem. 2016; 20(2):1-7.

22. MacArthur DG, North KN. A gene for speed? The evolution and function of alpha-actinin-3. Bioessays. 2004; 26:786-795.

23. Zanoteli E, Lotuffo RM, Oliveira AS, et al. Deficiency of muscle alpha-actinin-3 is compatible with muscle performance. J Clin Neuromuscul Dis. 2003; 20(1):39-42.

24. Ahmetov II, Druzhevskaya AM, Astratenkova IV, Popov DV, Vinogradova OL, Rogozkin VA. The ACTN3 R577X polymorphism in Russian endurance athletes. British J Sports Medicise. 2010; 44(9):649-652.

25. Garay AL, Levine L, Carter J. Single gene systems of blood. In: genetic and anthropological studies of olympic athletes. Garay, L. Levine and J. E. L. Carter(Eds.). New York, Academic Press. 1974; 165-187.

26. Jeon YK, Lee KH. ATCN-3 R577X gene genotype distri- 
bution of the difference between aerobic and anaerobic capacity in cross-country ski athletes. Korean J Sports Sci. 2014; 23(3):1255-1265.

27. Epperson WL, Burton RR, Beranuer EM. The effective- ness of specific weight training on simulated aerial combat maneuvering G-tolerance, viat. Space Environ Med. 1985; 56:534-539. 